\title{
Article \\ cpSSR and High-Resolution Melting Analysis (HRM) for Pinus pseudostrobus Lindl. Variety Genotyping and Discrimination
}

\author{
Liliana E. García-Valencia ${ }^{1,2}{ }^{\circledR}$, Jocelyn Pérez-García ${ }^{1}$, Miguel Ángel Vallejo-Reyna ${ }^{1}$, Roberto Reynoso-Santos ${ }^{3}$, \\ Jesús Vargas-Hernández ${ }^{4}\left(\mathbb{D}\right.$ and Florencia García-Campusano ${ }^{1, * \mathbb{C}}$
}

1 Centro Nacional de Investigación Disciplinaria en Conservación y Manejo de Ecosistemas Forestales, INIFAP, Ave. Progreso No. 5, Barrio de Santa Catarina, Coyoacán, Ciudad de Mexico, Distrito Federal 04010, Mexico; liligarciav@tec.mx (L.E.G.-V.); yoclinz21@gmail.com (J.P.-G.); vallejo.miguel@inifap.gob.mx (M.Á.V.-R.)

2 Tecnológico de Monterrey, Escuela de Ingeniería y Ciencias, Ave. Eugenio Garza Sada 2501, Monterrey, Nuevo León 64849, Mexico

3 Campo Experimental Centro de Chiapas, INIFAP, Km. 3 Carretera Ocozocoautla de Espinoza-Cintalapa, Burócrata, Chiapas 24160, Mexico; reynoso.roberto@inifap.gob.mx

4 Postgrado Forestal, Colegio de Postgraduados, Texcoco, Estado de Mexico 56230, Mexico; vargashj@colpos.mx

* Correspondence: garcia.florencia@inifap.gob.mx; Tel.: +52-553-626-8700 (ext. 80608)

check for updates

Citation: García-Valencia, L.E.; Pérez-García, J.; Vallejo-Reyna, M.Á.; Reynoso-Santos, R.; Vargas-Hernández, J.; García-Campusano, F. cpSSR and High-Resolution Melting Analysis (HRM) for Pinus pseudostrobus Lindl. Variety Genotyping and Discrimination. Forests 2022, 13, 200. https:/ / doi.org/10.3390/f13020200

Academic Editor: Dušan Gömöry

Received: 9 December 2021

Accepted: 21 January 2022

Published: 27 January 2022

Publisher's Note: MDPI stays neutral with regard to jurisdictional claims in published maps and institutional affiliations.

Copyright: (c) 2022 by the authors. Licensee MDPI, Basel, Switzerland. This article is an open access article distributed under the terms and conditions of the Creative Commons Attribution (CC BY) license (https:// creativecommons.org/licenses/by/ $4.0 /)$.

\begin{abstract}
The unambiguous identification of varieties within the Pseudostrobus complex is a key step to facilitate tree selection and monitoring in the wild as well as in plantations. Molecular tools provide a powerful approach for species delimitation; however, the use of DNA barcodes in this group has met limited success due to widespread haplotype sharing from lineage sorting, hybridization and introgression. Here, we evaluate the utility of real-time PCR coupled with high-resolution melting (HRM) to discriminate among Pinus pseudostrobus Lindl. var. pseudostrobus, apulcensis and oaxacana, from wild populations in central and southern Mexico, using chloroplast DNA sequence variants located within the $\operatorname{clpP}, y c f 2, \operatorname{trnL}(\mathrm{UAA})-\operatorname{trn} T(\mathrm{UGU})$ and $\operatorname{trnI}(\mathrm{CAU})-\operatorname{trn} F(\mathrm{GAA})$ loci. The markers ycf2/trnL(UAA)-trnT(UGU) produced clear melting patterns that separated the varieties pseudostrobus and oaxacana from type var. apulcensis, whereas $c l p P$ discriminated over $60 \%$ of var. oaxacana individuals. This assay underlines the usefulness of these less-used DNA regions as potential biological markers and exhibits the effect of geography on allele distribution and the likely presence of hybrids among the species and varieties.
\end{abstract}

Keywords: chloroplast DNA; conifers; field populations; genotyping; real-time PCR; high-resolution melting curves

\section{Introduction}

Pinus pseudostrobus Lindley is an economically important timber species distributed in Mexico and Central America throughout a wide altitude range (1600-3300 m above sea level) [1]. The species grows under a broad range of environmental conditions and exhibits considerable phenotypic variability and plasticity [2,3]. This has led to the recognition of different varieties or ecotypes, because of either adaptive processes [4,5] or hybridization events with Pinus montezumae Lambert and possibly other related species, particularly in populations within the Trans-Mexican Volcanic Belt [4,6-8]. As a result, the taxonomy of the species remains controversial; while Martínez (1948) [9] recognized up to five morphologically distinct varieties (var. pseudostrobus (typical), oaxacana, apulcensis, coatepecensis and estevezii), other authors have considered only two or three with different types and var. oaxacana as Pinus oaxacana Mirov $[1,3,6]$. The problem is further complicated by the fact that the distribution of the different varieties shows considerable overlap [3,6], which can create confusion when carrying out collections, since they are not always readily distinguishable in the field. The morphological differentiation among varieties is mostly based on apophysis elongation, peduncle length and cone size and shape [1,3]. 
Notwithstanding, the Pseudostrobus varieties exhibit important differences regarding their habitat preference and production potential; except for var. estevezii, which grows in northeastern Mexico, the other four varieties grow in central and southern Mexico. While var. pseudostrobus grows at higher altitudes and prefers deep and fertile soil, var. apulcensis grows at lower elevations and lower humidity [6] and var. coatepecensis also grows at low elevations, but only in the state of Veracruz, and var. oaxacana shows preference for dry areas. Provenance trials comparing growth traits, survival and frost damage in var. pseudostrobus and var. apulcensis show these to have important differences in growth and adaptive characteristics [5]. Therefore, the establishment of a fast and precise system to discriminate among species and varieties, that ease evaluation and monitoring, is important for tree breeding efforts and the establishment of seed and clonal orchards.

Chloroplast DNA (cp), such as intergenic spacers and genes, for example trnK-matK, $a t p B-r b c L, n d h F-r p l 32, p s b J-p e t A, t r n L-t r n F$ and matK-ycf1, has been used in conifer species for identification, phylogenetic and population genetic studies $[7,10,11]$. In particular, simple sequence repeats (SSRs or microsatellites) are often informative for finer-scale patterns within and between populations because they are highly polymorphic; therefore, they are applied to visualize intraspecific genetic variability [12]. The advantages of using chloroplast microsatellite sequences (cpSSRs) in Pinus spp. include its highly conserved genome sequence, low (if any) recombination and paternal inheritance [13-15]. However, the description of cpSSRs for Pinus is limited, when compared to angiosperms [16-19].

Nevertheless, studies within the P. pseudostrobus complex and other pines of the Montezumae clade have shown that they exhibit low levels of sequence divergence and minimal phylogenetic structure $[11,12,20]$, indicating that the taxonomic and phylogenetic issue is far from resolved. However, the identification and testing of new genetic markers to discriminate different varieties in a fast and inexpensive manner could provide a useful tool for forestry research in these species.

High-resolution melting analysis (HRM) is a highly sensitive, rapid and relatively inexpensive PCR-based method used for mutation scanning and genotyping. HRM detects SNPs (single-nucleotide polymorphisms) and small insertions or deletions in amplified DNA fragments by comparing changes in the dissociation rate of double-stranded DNA (dsDNA) to single-stranded DNA (ssDNA) with the increase in temperature [21]. To monitor these changes, a fluorescent dye is added to the PCR mix that intercalates into DNA and fluoresces only when bound in dsDNA; changes in fluorescence occur as the temperature rises and the DNA strands separate. The thermally induced melting behavior depends on the thermodynamic characteristics of the PCR product, defined by sequence length, nucleotide order, GC content and complementarity [21].

HRM is used widely for allelic discrimination of well-characterized SNPs, or to screen for the existence of unknown variants [22], mainly in clinical and diagnostic studies [23,24]. When combined with short nuclear or chloroplast sequences, DNA barcodes (Bar-HRM), it provides a powerful tool for species and variety identification and authentication [25]. EST, SSR and characterized SNP markers have been used to discriminate among different varieties of cherry [26], olive [27] and lentil [25], among others. Likewise, distinguishing the origin of Pinus radiata D.Don and Pseudotsuga menziesii (Mirb.) Franco timber with the trnL(UAA) locus was accomplished, even by using wood samples [28].

Few studies have attempted to incorporate HRM analysis into wild population studies. Using nuclear DNA, HRM analyses allowed the identification of swordfish populations [29], whereas the internal transcribed spacer region 2 ribosomal DNA (ITS2 rDNA) was tested for genotyping monotypic dinoflagellates [30] and strain identification and polymorphism characterization in field endosymbiotic Wolbachia was achieved by targeting a specific surface protein gene [31]. Examples in plants include chloroplast haplotype identification in Arenaria spp. [32], as well as the delimitation of different Mediterranean Pinus species using the $\operatorname{trn} L(\mathrm{UAA})$ locus [33]. This technology was also tested to screen for haplotype variation in the genus Cyclopia by using twelve non-coding cpDNA and applied to C. subternata wild populations with three markers within the atpI-atpH, $\operatorname{trn} G-\operatorname{trn} G 2 \mathrm{G}$ and $\operatorname{trn} Q-5^{\prime} r p s 16$ 
intergenic spacers [34]. As part of a program to establish P. pseudostrobus provenance trials and seed orchards in central and southern México, the aim of this study was to test various chloroplast simple sequence repeats (cpSSRs) to be used in combination with HRM for the rapid detection and differentiation of four P. pseudostrobus varieties (var. pseudostrobus, var. apulcensis, var. oaxacana and var. coatepecensis) obtained from wild populations growing in the region.

\section{Materials and Methods}

\subsection{Plant Material}

Needle tissue from 195 P. pseudostrobus trees growing in different populations in the central and southern part of the natural range was collected (Figure 1, Table S1). Individuals were phenotypically identified in the field by the collectors and selected based on their superior traits for the establishment of provenance trials and seed orchards. Ninetyseven samples were classified as var. pseudostrobus (provenances: Mexico State, Chiapas, Puebla, Tlaxcala, Oaxaca, Veracruz, Michoacán and Jalisco), 53 belonged to var. oaxacana (provenances: Oaxaca, Veracruz and Puebla), 31 were var. apulcensis (provenances: Hidalgo, Chiapas and Veracruz) and 16 were var. coatepecensis (provenance: Veracruz) (Figure 1). Trees selected from the same locality grew at least $100 \mathrm{~m}$ apart. From two to three small branches from each tree were collected and stored at $-80^{\circ} \mathrm{C}$ until used. Eight $P$. montezumae tissue samples were obtained from seedling needles from a commercial nursery in Puebla (four), needles from wild mature trees in Mexico State (two) and megagametophytes from seeds (Colpos seed collection) (two).

\subsection{DNA Extraction}

Total DNA was extracted and purified from $200 \mathrm{mg}$ of needle tissue using a modified CTAB based method [35]. DNA concentration and quality were verified spectrophotometrically with NanoDropTM ND-1000 (Nanodrop Technologies Inc., Wilmington, DE, USA) and visually by standard agarose gel electrophoresis $(0.8 \%$ agarose in TBE $1 \times)$. An aliquot of DNA was eluted in nuclease-free water to a final working stock of $10 \mathrm{ng} / \mu \mathrm{L}$.

\subsection{Primer Design and Selection}

We researched the literature to identify known DNA regions that exhibited adequate polymorphism to perform a high-resolution melting (HRM) analysis. Furthermore, we aligned the complete chloroplast sequences for P. montezumae (JN854183.1) and P. pseudostrobus (JN854178.1), obtained from the National Center for Biotechnology Information (NCBI) with ClustalW [36]. Additionally, we included a consensus sequence obtained from an alignment of Pinus oocarpa Shiede ex Schltdl (KY963969.1), Pinus taeda Linnaeus (FJ899561.2) and Pinus greggii Engelm. ex Parl. 1867 (JN854198.1), that targeted regions of commonly used chloroplast markers in Pinus genetic diversity studies $[7,10,12,37]$ (Figure 1).

To ensure detection by HRM, we established the following criteria for primer selection: (1) the targeted region exhibited polymorphism between $P$. pseudostrobus and P. montezumae; (2) region length was of less than $200 \mathrm{bp}$; (3) polymorphisms consisted mainly of G/C for $\mathrm{T} / \mathrm{A},(\mathrm{TT} / \mathrm{AA})_{2} ;(4)$ insertions or deletions of at least $2 \mathrm{bp}$. The tested primer pairs are summarized in Table 1. Amplification by each primer pair was verified using DNA from P. pseudostrobus var. pseudostrobus and P. montezumae. A standard PCR was performed in $10 \mu \mathrm{L}$ reactions, using $1 \mu \mathrm{L}$ of DNA at $10 \mathrm{ng} / \mu \mathrm{L}$ and Taq Platinum ${ }^{\circledR}$ (Invitrogen), according to the manufacturer's instructions. The cycling parameters were: $94{ }^{\circ} \mathrm{C}$ for $2 \mathrm{~min}$, followed by 35 cycles of $94{ }^{\circ} \mathrm{C}$ for $30 \mathrm{~s}, 56^{\circ} \mathrm{C}$ for $30 \mathrm{~s}, 72^{\circ} \mathrm{C}$ for $1 \mathrm{~min}$ and a final extension of $72{ }^{\circ} \mathrm{C}$ for $5 \mathrm{~min}$. Gel electrophoresis was performed to confirm amplification and to initially screen for variation in amplicon size. Only primers that amplified for both species were used. 


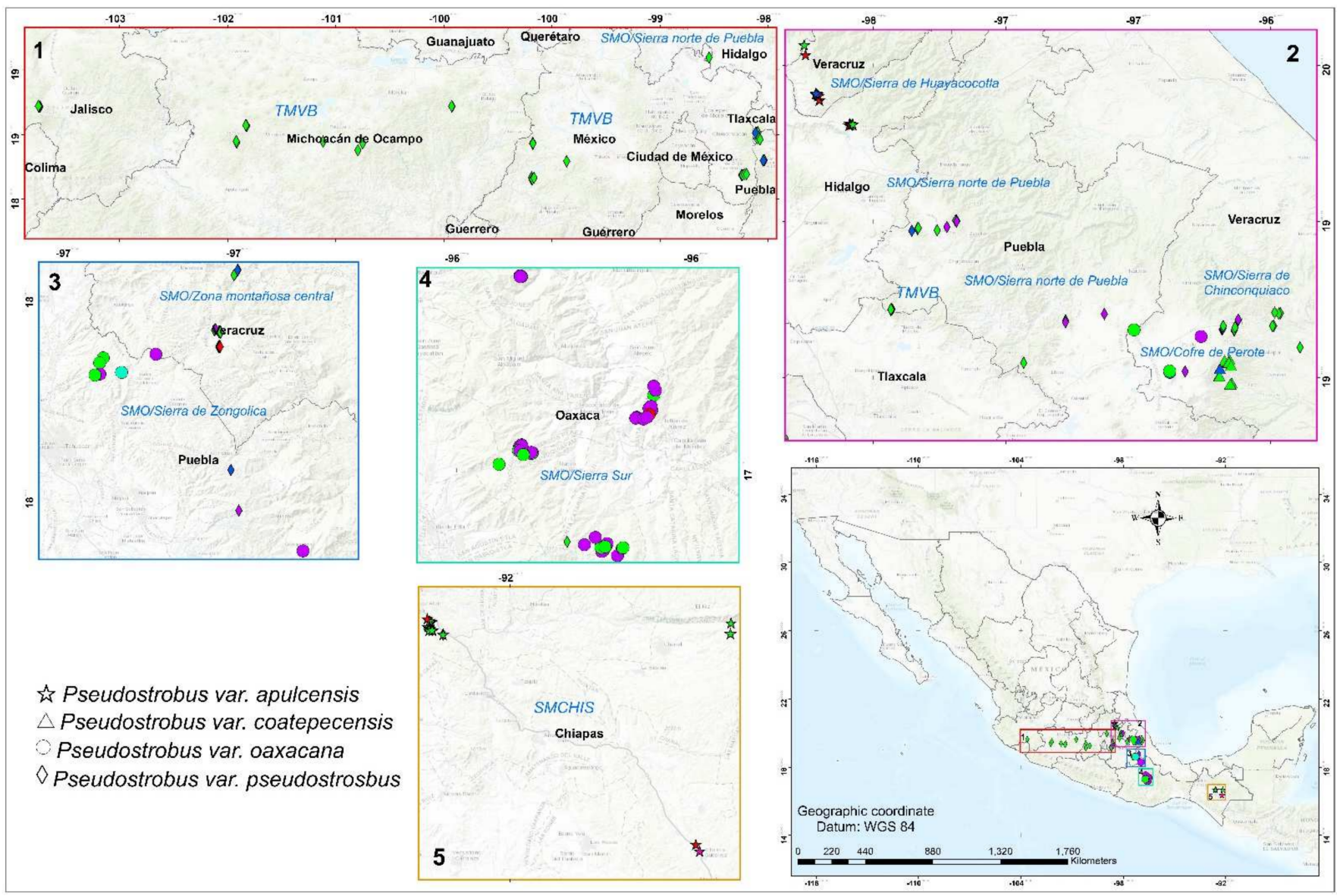

Figure 1. Geographic distribution of sampled populations of Pinus pseudostrobus varieties in central and southern Mexico. Different shapes represent varieties: pseudostrobus (diamond), apulcensis (star), oaxacana (circle) and coatepecensis (triangle). Box outline color and number (1-5) matches region indicated in the map, whereas colors reflect different haplotypes: A (green), B (purple), C (blue), D (red), E (magenta), F (turquoise), G (black), H (pink) and I (yellow). TMVB, Trans-Mexican Volcanic Belt; SMO, Sierra Madre Oriental; SMCHIS, Sierra Madre de Chiapas.

Table 1. Candidate microsatellite primers tested for high-resolution melting analysis.

\begin{tabular}{|c|c|c|c|}
\hline Locus & Polymorphism & Forward Primer $\left(5^{\prime}-3^{\prime}\right)$ & Reverse Primer $\left(5^{\prime}-3^{\prime}\right)$ \\
\hline $\begin{array}{c}c l p P(30204) \\
\text { Wofford et al. (2014) }\end{array}$ & Indel $4 \mathrm{G}$ & CGTAGCGGAAGGTTGATCTCAT & TTCGGATTGATCCTAACCATACCA \\
\hline $\begin{array}{c}\text { trnS-trnG IGS } \\
\text { Dong et al. (2012) }\end{array}$ & $\mathrm{G}-\mathrm{T} ; \mathrm{T}-\mathrm{G}$ & TTGTCTTCTTCGGACTCCTACCCA & GAAGGGTTCTCTATCTATTTAGGGT \\
\hline$c p D N A 5$ * & indel TACAG & ACCCGCAACTTCCGTCTTGA & CCTATCTAGCGCCTATCATGGA \\
\hline$c p D N A 6^{*}$ & indel AAATTAT; G-T & CCACATTAACATATTGACCСАTACСТ & AGATCTTTCAATTGCAGAACAGATAGG \\
\hline$c p D N A 7^{*}$ & A-G; indel CGAAT & CCAGAGCTTTGGCTCCCATT & GATCGGATCCAAGTATCTTCCCA \\
\hline$c p D N A 8^{*}$ & indel TCСССТТСТ & TGCTCAATATTGGGTGGGAGAAA & TCGATTGGGGTAGAGATAGAGAAGG \\
\hline$c p D N A 9$ * & indel GG & TCCTATGCGGGAACTGGAAT & TACTCGCAGTGTATTGTGGC \\
\hline cpDNA10 * & indel (CTT) 4 & GCACAATCCGTTCAACTCTCTT & TCCCGTGCCTAATAGCTTTCTC \\
\hline
\end{tabular}

\subsection{Real-Time PCR and HRM Analysis}

To standardize the HRM conditions and test the discriminative power of primer pairs, three individuals from different populations of P. pseudostrobus var. pseudostrobus from Jalisco and Michoacán, three of var. oaxacana from Oaxaca, three of var. apulcensis 
from Hidalgo, two of var. coatepecencis from Veracruz and four of P. montezumae from a commercial nursery were tested. Once the conditions were established, the HRM assay was performed using DNA from 184 additional P. pseudostrobus individuals. All experiments were carried out on a CFX96 cycler Real-Time PCR Detection System (Bio-Rad Laboratories, Inc., Hercules, CA, USA). Reactions (final volume of $20 \mu \mathrm{L}$ ) were set up in triplicate in transparent PCR plates (96 wells), with a $1 \times$ Type-it HRM PCR Kit (Qiagen ${ }^{\circledR}$ ) that contained EvaGreen $^{\circledR}, 800 \mu \mathrm{M}$ of each primer and $1 \mu \mathrm{L}$ of DNA at $10 \mathrm{ng} / \mu \mathrm{L}$. The cycling parameters were as follows: $95^{\circ} \mathrm{C}$ for $5 \mathrm{~min}$, followed by 40 cycles at $95{ }^{\circ} \mathrm{C}$ for $10 \mathrm{~s}, 60{ }^{\circ} \mathrm{C}$ for $30 \mathrm{~s}$ and $72{ }^{\circ} \mathrm{C}$ for $10 \mathrm{~s}$. After the PCR amplification steps, the melting curves for the products were generated by heating at $0.2^{\circ} \mathrm{C}$ increments, at a rate of $10 \mathrm{~s} / \mathrm{step}$, with temperatures ranging from 65 to $95^{\circ} \mathrm{C}$. Plate set-up, PCR parameters, data acquisition and monitoring the amount of fluorescence for each sample was performed with CFX-Manager Software v1.6 (Bio-Rad Laboratories, Inc. Hercules, CA, USA).

A post-PCR HRM analysis of the melting curves was carried out using Precision Melt Analysis ${ }^{\mathrm{TM}}$ software (Bio-Rad), which automatically clustered samples according to their melting profile (temperature and shapes of the melting curves). The confidence threshold for a sample to be included in a cluster was $99 \%$. The melting curves were normalized using the pre- and post-melting temperature ranges automatically, given by software, or manually to achieve better results. Derivative plots were also generated to assess the different melting peaks. PCR products with different melting profiles were sequenced (Macrogen) in two directions to validate the results. The sequences were aligned with SeaView software [38] and MUSCLE (MUltiple Sequence Comparison by Log-Expectation) [39] a multiple sequence alignment tool. After sequencing, the amplified chloroplast DNA fragments were concatenated because they were not subject to recombination events. With this information, the haplotype identity was assigned in each P. pseudostrobus sample according to the method shown by Galuszynski and Potts [34].

\section{Results}

To evaluate the effectiveness of high-resolution melting (HRM) as a tool to discriminate among the four Pseudostrobus varieties sampled, we first standardized the conditions using a small number of "type" trees of each taxon (var. pseudostrobus, oaxacana, apulcensis and coatepecensis), according to morphological data provided by the collectors. As a first criterion, we selected the targeted region based on in silico sequence polymorphisms between P. pseudostrobus var. pseudostrobus and P. montezumae, considering the need to differentiate between these and potential hybrids. PCR analyses were performed and amplicons were separated using gel electrophoresis to screen the different primer pairs and those that produced noticeable changes in size were prioritized for qPCR testing. The amplicons were then subjected to the HRM curve analysis and the most promising primers were chosen considering whether they clustered the different varieties; those that exhibited little inter-varietal polymorphisms (trnS-trnG IGS, $c p D N A 5$ and $c p D N A 9)$ were not followed. No single target region allowed the simultaneous distinction of all varieties to be performed, although the sequential use of two primer pairs allowed us to discriminate among the type individuals of var. pseudostrobus, oaxacana and apulcensis. However, we were unable to detect a marker that could separate var. coatepecensis from var. pseudostrobus.

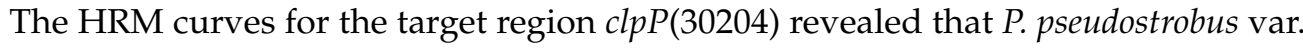
oaxacana could be visually separated from var. pseudostrobus/coatepecensis/apulcensis and P. montezumae, as these were highly characteristic for each group, indicating two potentially polymorphic amplicons (red and green curves in Figure 2A). Sanger sequencing confirmed the amplicons of 162 bp for var. pseudostrobus/coatepecensis/apulcensis/P. montezumae (allele

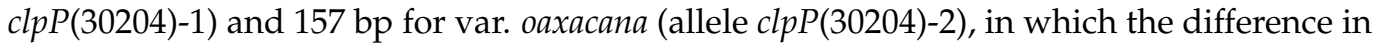
size was the result of an indel of (G)5 at position 99 (Figure 2B). 

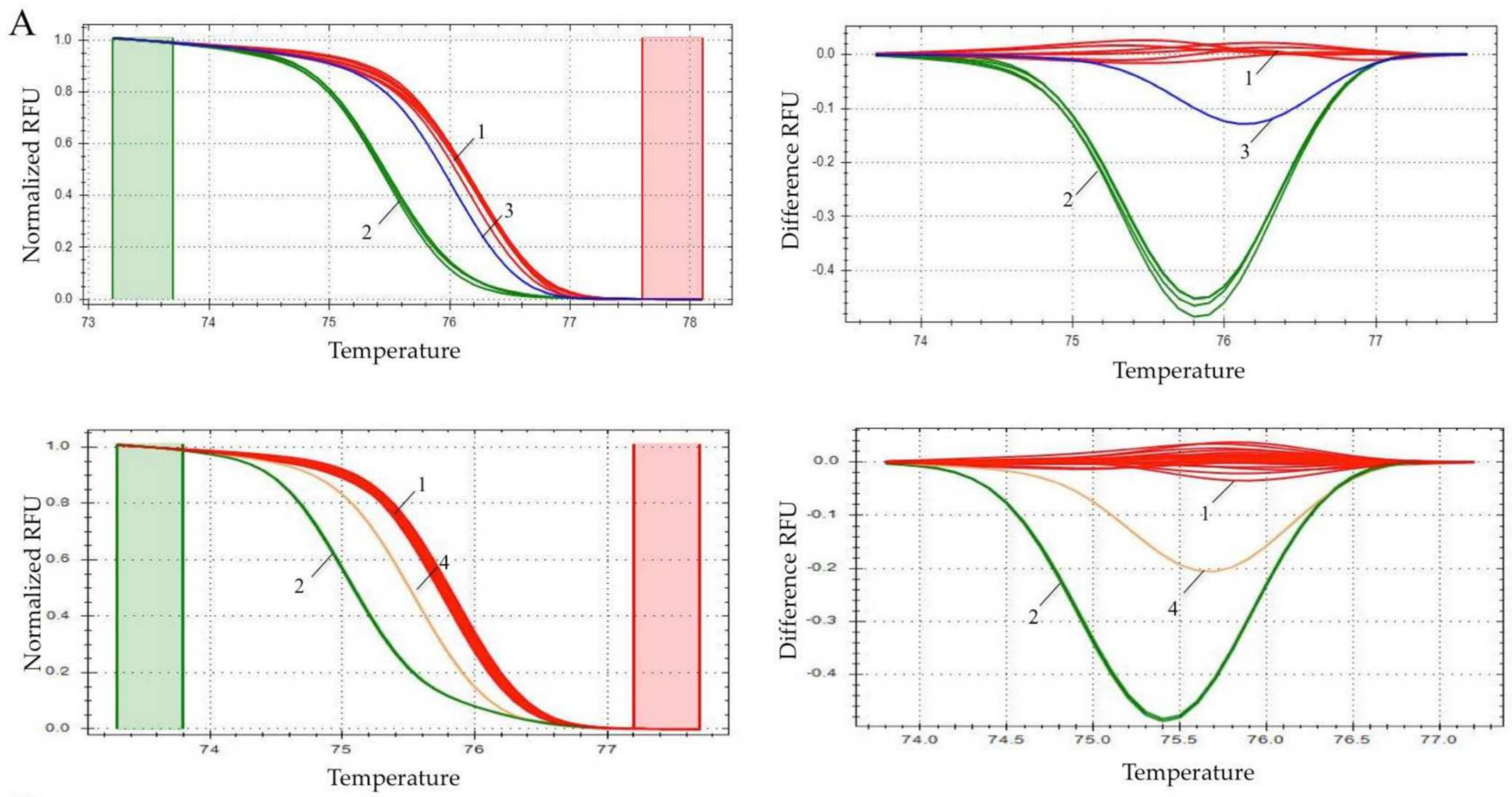

B
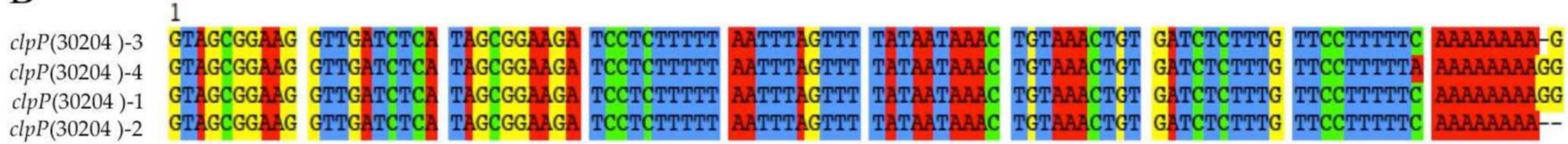

101

$\begin{array}{ll}\operatorname{clp} P(30204)-3 & \text { GGGGGG: } \\ \operatorname{clp} P(30204)-4 & \text { GGGGGG }\end{array}$

$\operatorname{clpP}$ (30204)-1

$\operatorname{clp} P(30204)-2$

--- GGGA

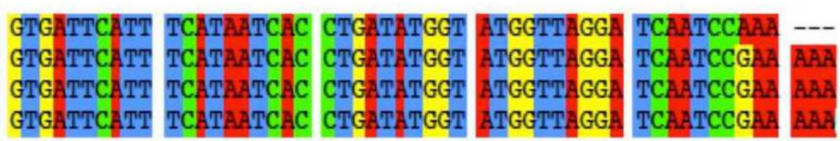

Figure 2. Real-time PCR-HRM analysis with primer set $\operatorname{clp} P(30204)$. (A) Representative normalized

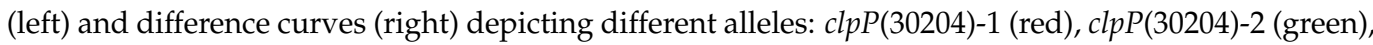
clpP(30204)-3 (blue) and clpP(30204)-4 (yellow). (B) Sequence alignment comparing the amplicons of the different alleles including primers.

In the interest of further discriminating among var. pseudostrobus, var. coatepecensis, var. apulcensis and P. montezumae, various primer pairs were tested (Table 1); of these, cpDNA10 and $c p D N A 8$ produced HRM patterns that allowed us to perform the most consistent grouping of the taxa, in accordance with their morphological identification. The $c p D N A 10$ primer produced two discernible HRM melting profiles (Figure 3A), corresponding to a $175 \mathrm{bp}$ amplicon for the var. pseudostrobus/coatepecensis/oaxacana (allele cpDNA10-1) and a $163 \mathrm{bp}$ amplicon for var. apulcensis/P. montezumae (allele cpDNA10-2) that resulted from a (TCTTCC) 2 at position 60 (Figure 3B). Likewise, the $c p D N A 8$ primer clustered samples of var. pseudostrobus/coatepecensis/oaxacana (cpDNA8-1) in a different group from P. montezumae (cpDNA8-2); however, it subdivided the five different var. apulcensis samples from Hidalgo into three groups, i.e., one with var. pseudostrobus/coatepecensis/oaxacana (cpDNA8-1), two with P. montezumae (cpDNA8-2) and a final two that were unique to the individuals ( $c p D N A 8-3)$ (Figure 3C). Sequencing showed that allele $c p D N A 8-1$ was $111 \mathrm{bp}$ long, whereas $c p D N A 8-2$ had a length of $94 \mathrm{bp}$ and they differed by indels at positions 35 (CTCCCCTTTT) and 60 (TCTCTA) (Figure 3D). The unique HRM profile found for $c p D N A 8-3$ in two specimens was due to the amplification of a double band and could not be adequately sequenced (data not shown). 
A $c P D N A 10$
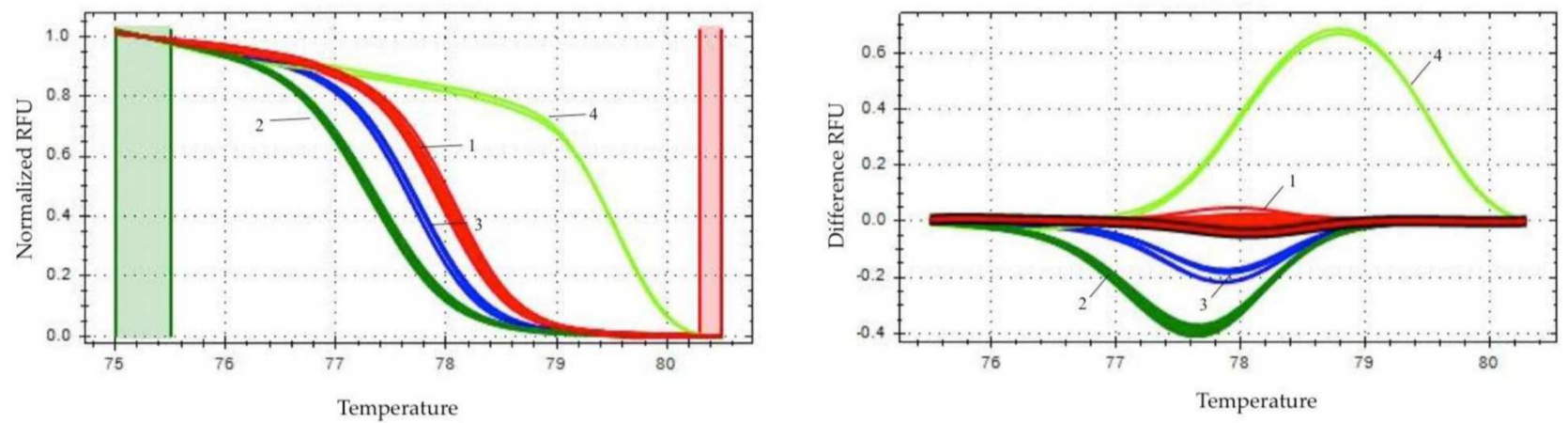

B
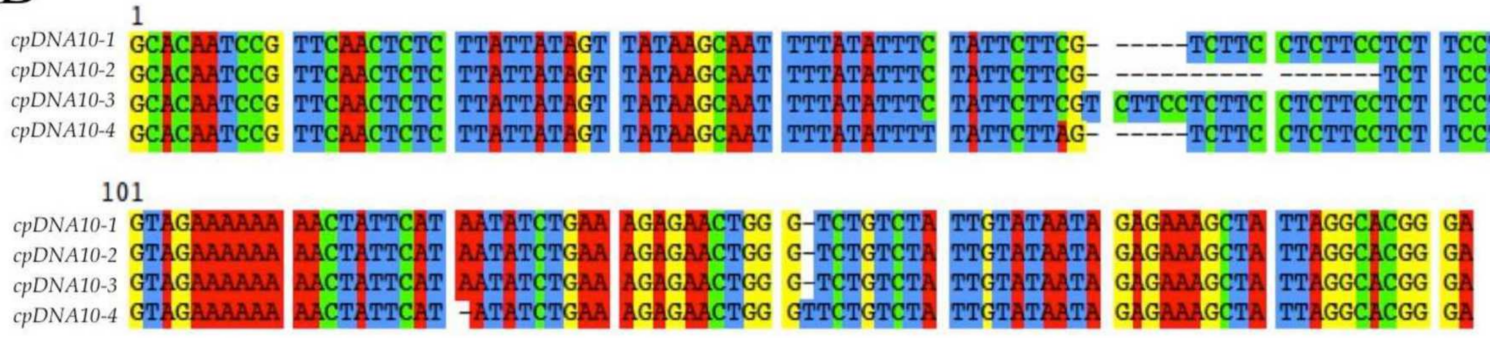

C

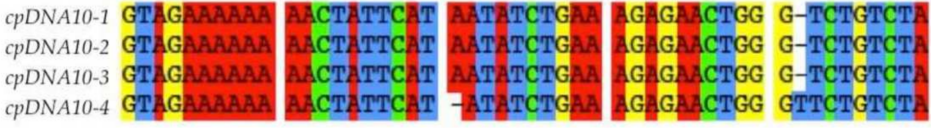
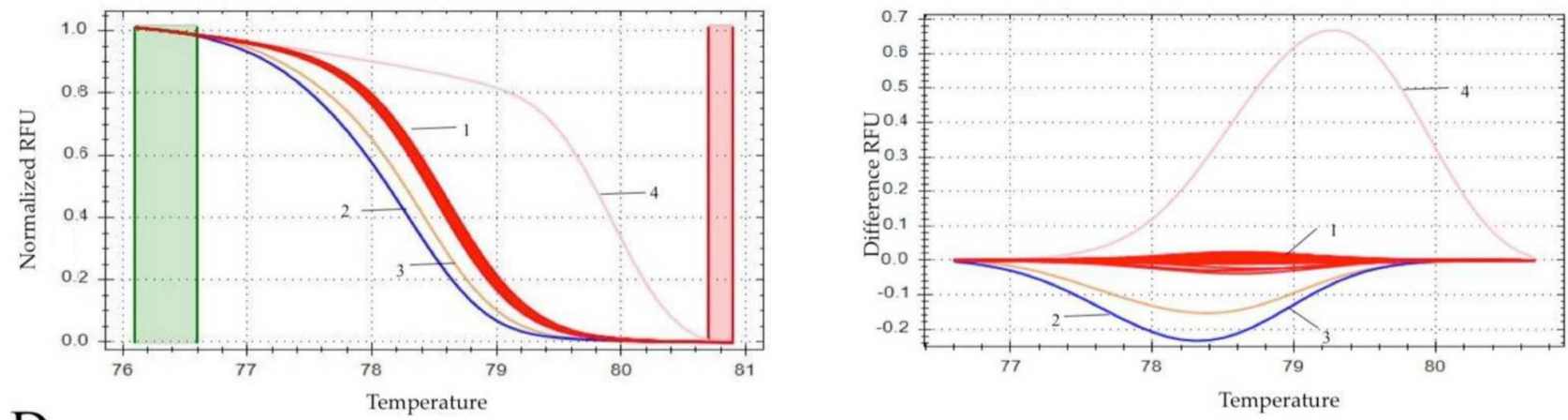

D
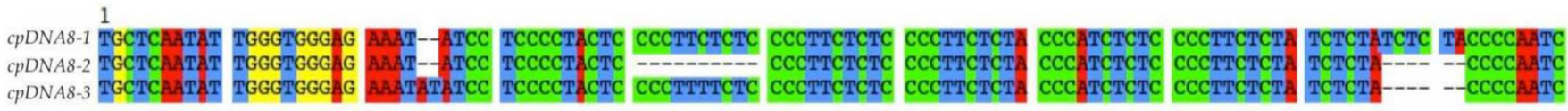

111

cPDNA8-1 GAA

cpDNA8-2 GA-

cPDNAs-3 GA

Figure 3. Real-time PCR-HRM analysis with primer sets $c p D N A 10$ and $c p D N A 8$. (A) Representative normalized (left) and difference curves (right) depicting different alleles: $c p D N A 10-1$ (red), cpDNA102 (green), $c p D N A 10-3$ (blue) and $c p D N A 10-4$ (light green). (B) Sequence alignment comparing the amplicons of the different $c p D N A 10$ alleles. (C) Representative normalized (left) and difference curves (right) depicting different alleles: $c p D N A 8-1$ (red), $c p D N A 8-2$ (blue), $c p D N A 8-3$ (yellow) and $c p D N A 8-4$ (pink). (D) Sequence alignment comparing the amplicons of alleles from $c p D N A 8-1$ to -3 ; cpDNA8-4 was not sequenced.

We further used $\operatorname{clpP}(30204), c p D N A 8$ and $c p D N A 10$ to investigate their convenience in distinguishing among the varieties of Pseudostrobus, as well as to detect other potential polymorphisms (alleles) in these chloroplast regions, in 184 additional adult trees growing throughout Mexico State, Puebla, Chiapas, Tlaxcala, Oaxaca, Veracruz, Michoacán and 
Jalisco, as well as in four additional P. montezumae specimens. Screening with the $\operatorname{clpP(30204)}$ marker showed that $64 \%$ of var. oaxacana specimens (34 of 53 trees) collected in Oaxaca, Puebla and Veracruz exhibited the $\operatorname{clpP}(30204)-2$ variant, which increased to $71 \%$ when only populations from regions within the Sierra Madre del Sur in Oaxaca were considered. The remainder grouped with var. pseudostrobus (allele clpP (30204)-1). Of the other analyzed taxa, most exhibited $\operatorname{clpP}(30204)-1$, as expected, although eleven var. pseudostrobus obtained from Puebla, Oaxaca and Veracruz, as well as a single var. apulcensis individual, shared the $\operatorname{clpP}(30204)-2$ allele (Table S1). Two unique melting curve profiles were distinguished for a single var. pseudostrobus specimen from Michoacán (Figure 2A) and a var. apulcensis specimen from Veracruz. The sequencing of the first revealed the deletion of $G$ in position 99 (allele $\operatorname{clp} P(30204)-3$, sequence length of $162 \mathrm{bp}$ ) (Figure 2B) and the substitution of

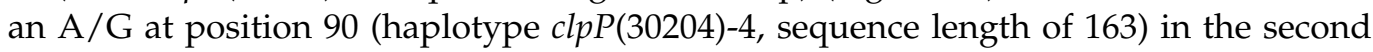
(Figure 2B).

Screening populations with $c p D N A 8$ and $c p D N A 10$ showed that the HRM profiles of most var. pseudostrobus, oaxacana and coatepecensis clustered together and the sequencing of random samples showed that they exhibited the $c p D N A 8-1$ and $c p D N A 10-1$ alleles, as expected. Twelve representatives of var. pseudostrobus, two from var. oaxacana and two from var. coatepecensis formed a different cluster together with P. montezumae and sequencing verified that they carried the $c p D N A 8-2$ and $c p D N A 10-2$ alleles. Although, in most cases, both markers clustered samples similarly, of the 26 trees identified as var. apulcensis, cpDNA10 distinguished a greater number of individuals and clustered them accordingly with $P$. montezumae, which was further confirmed by sequencing (Table S1); specifically, eight specimens from Chiapas and Veracruz clustered in a typical pattern shown by samples obtained from Hidalgo (type locality, $c p D N A 10-2)$. Additional melting profiles with $c p D N A 10$ reflecting different alleles were detected and confirmed by sequencing (Figure 3B); two specimens from Jalisco showed an insertion (TCTTCC) at position 59 (sequence length $181 \mathrm{bp} ; c p D N A 10-3)$. A single specimen from Veracruz presented an allele (cpDNA10-4) with various base changes throughout its sequence (T/C at position 50 , $\mathrm{A} / \mathrm{C}$ at 58, a deletion of $\mathrm{A}$ at 121 and an insertion of a $\mathrm{T}$ at 142) that had greater homology (98\%) with P. devoniana Lindley 1839 rather than P. pseudostrobus or P. montezumae. This last sample also exhibited a different allele with $c p D N A 8$ (106 bp; $c p D N A 8-4)$ that resulted from the insertion of AT at position 23, the insertion at position 35 present in the allele $c p D N A 8-1$ with a $\mathrm{T} / \mathrm{C}$ at position 46; however, it also exhibited the deletion characteristic of $c p D N A 8-2$ at position 60 .

Considering the three markers, we detected 11 alleles in the Pseudostrobus populations, which conformed to 10 haplotypes (A-J). Haplotypes A-D were the most widely distributed, whereas F-I were each represented by one or two individuals (3.5\% of the total samples); thus, they may be considered rare and are unlikely to help differentiate among varieties, even though, at this stage, they did evidence the usefulness of HRM in detecting allelic variants. The J haplotype was unique to individuals of var. apulcensis from Hidalgo and was not found in specimens of this variety from other regions. Haplotype A clustered most of the representatives of the species-73\% of var. pseudostrobus, $47 \%$ of var. apulcensis, $32 \%$ of var. oaxacana and $88 \%$ of var. coatepecensis (Figure 4) - and was clearly distinguished from haplotype $\mathrm{C}$, which conformed to P. montezumae (Figure 4). Interestingly, members of var. apulcensis showed the most variation; specimens from Hidalgo exhibited the C and J haplotypes; in Sierra Huayacocotla (Veracruz), the majority conformed to a unique D haplotype (56\%), although other less frequent haplotypes were detected (A, B, H and I), while most specimens from Sierra Madre of Chiapas conformed to haplotype A and sporadically D or F (Figure 4). Haplotype B was more common in var. oaxacana samples from southern Oaxaca (70\%), which contrasted with those obtained further north and from Veracruz and Puebla, where the frequency of haplotype A increased to nearly $50 \%$. 

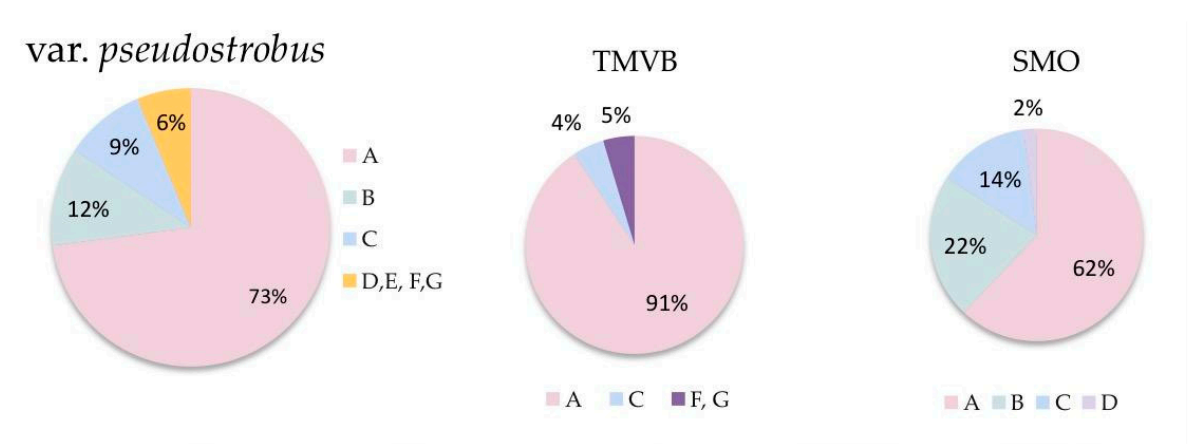

var. coatepecensis

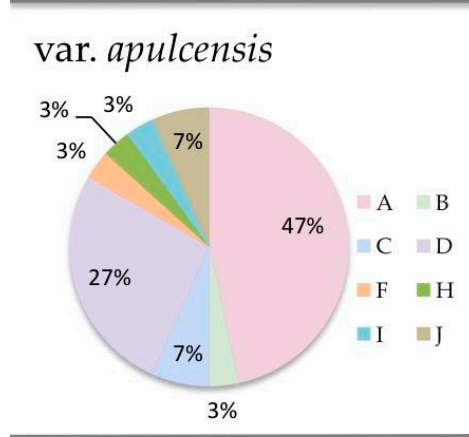

\section{var. oaxacana}

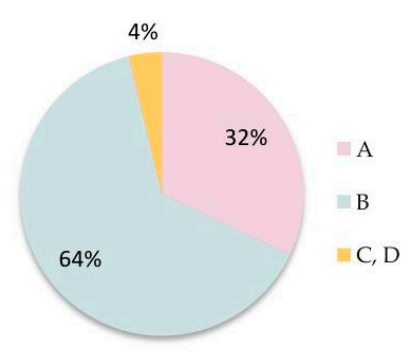

SMO

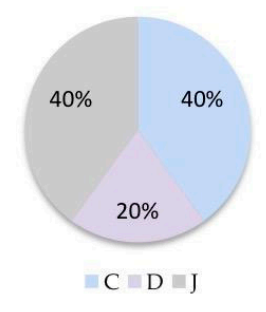

$\mathrm{SMO}$

(Cofre de Perote)

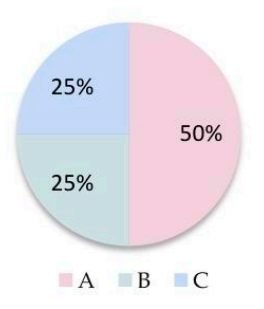

SMO

(Sierra de Huayacocotla)

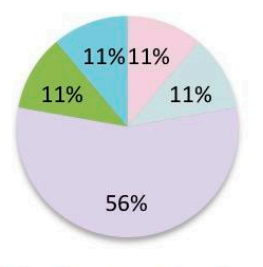

$\pm \mathrm{A}=\mathrm{B} \approx \mathrm{D} \approx \mathrm{H} \| \mathrm{I}$

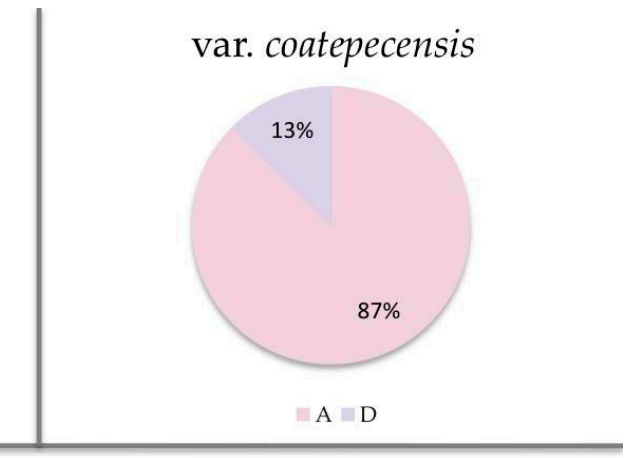

Sierra Madre de Chiapas

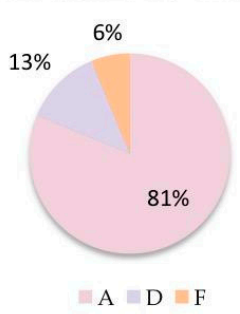

$\mathrm{SMO}$

(Sierra del Sur)

$\mathrm{SMO}$

(Sierra de Zongolica)
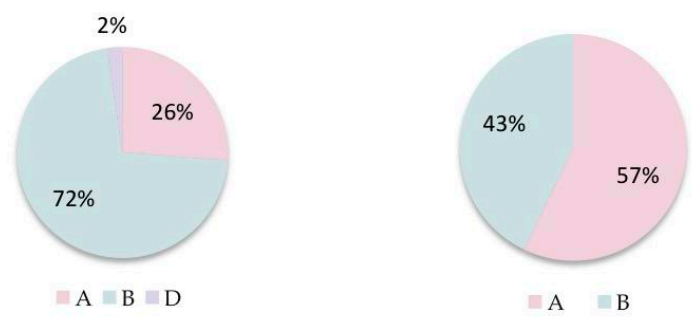

Figure 4. Haplotype frequencies found for the different varieties in the Trans-Mexican Volcanic Belt (TMVB), different regions of the Sierra Madre Oriental (SMO) and Sierra Madre de Chiapas.

\section{Discussion}

The unambiguous identification and classification of members of the subsection Ponderosae and, particularly, of the Pseudostrobus complex has generally been a challenge for researchers and for collectors in the field. The group exhibits a mosaic of morphological variation throughout its wide distribution range $[4,40]$, which is further enhanced by its tendency to form natural hybrids with P. montezumae and, possibly, P. hartwegii [7]. The use of HRM coupled with SSR markers represents a means to direct sampling of representative individuals from natural populations, as well as the potential to explore genetic diversity for breeding and selection purposes. In order to assign individuals morphologically classified as P. pseudostrobus var. pseudostrobus, var. apulcensis, var. oaxacana or var. coatepecensis, we reviewed both the literature and sequences from NCBI to identify candidate markers to test them as barcodes for HRM analysis.

Our search showed that many of the reported chloroplast regions commonly used in phylogenetic studies, including the $\operatorname{trn} L(\mathrm{GAU})-\operatorname{trn} A(\mathrm{UGC})$ spacer, $r b c L$, matK, ycf1, $\operatorname{trnK}(\mathrm{UUU})$ spacer, $\operatorname{trn} G(\mathrm{UCC})$ intron, $r p s 2, p s b J-p e t A$ spacer, downstream $\operatorname{trn} S$ (UGA) and psbA-trnH intergenic spacer, were identical between P. pseudostrobus and P. montezumae; therefore, they were ineffective in discerning between the species, or varieties. This is consistent with reports of their limited applicability to assess phylogenetic relationships at lower taxonomic levels [20,41,42]. The low genetic variation exhibited at these sites is consistent with the lack of phylogenetic resolution among the taxa within the Montezumae clade (which includes P. pseudostrobus, P. montezumae, P hartwegii and Pinus maximinoi H.E. Moore, 
1967) and is attributed to interspecific gene flow, introgression and incomplete lineage sorting that could explain the sharing of plastid haplotypes among pine species $[7,11,43]$. Other markers, such as IRF169 intron 1 and rpoB [44], which showed a single base pair change, were also eliminated from the study, since we wanted to ensure a clear-cut HRM profile to differentiate among varieties. The type of polymorphism these regions presented (single base pair change of $\mathrm{T}$ and $\mathrm{A}$ ) produced a subtle temperature shift $\left(0.1^{\circ} \mathrm{C}\right.$ ) that could potentially pass unnoticed in the HRM analysis due to the detection limit of the technique. Although the base change in trnS-trnG IGS (G/T) [45] produced a clear shift in the melting pattern with HRM that could be useful to distinguish P. pseudostrobus from P. montezumae, a preliminary assay indicated this was not the case for Pseudostrobus varieties (data not shown), suggesting low or no intraspecific polymorphisms.

The full chloroplast sequences reported for P. pseudostrobus, P. montezumae and other species of Pinus were compared to identify candidate loci that were polymorphic among these taxa, which could potentially produce contrasting melting patterns with HRM. Primer pairs $c p D N A 10$ and cpDNA8 unambiguously separated $88 \%$ of var. pseudostrobus from P. montezumae. Primer pair $c p D N A 10$ is located within the ycf2 locus; this region has been proposed as a candidate or supplementary region for phylogenetic analysis at lower taxonomic levels in Pinus [46] and shown its potential as a barcode to discriminate among species of the Pinus mugo complex [47]. Although, in Pinus ycf2, it is less variable than ycf1 [46], our in silico analysis showed it allowed us to distinguish P. pseudostrobus from P. montezumae, reinforcing the view that this chloroplast locus is worth further exploration. Primer pair $c p D N A 8$ is located in the $\operatorname{trnL}(\mathrm{UAA})-\operatorname{trnT}(\mathrm{UGU})$ intergenic spacer, similar to the PCL2T1 [12], although it encompasses a shorter region in order to facilitate HRM detection. When tested to explore their potential to discriminate among Pseudostrobus varieties, both $c p D N A 10$ and $c p D N A 8$ produced two main alleles that clustered var. pseudostrobus/var. oaxacana/var. coatepecensis and var. apulcensis with $P$. montezumae. The grouping of different individuals produced by these primer pairs differed only in 15 of 196 specimens, with cpDNA10 showing greater resolution to separate var. apulcensis/P. montezumae from the larger var. pseudostrobus cluster. This general melting pattern posed the additional challenge of identifying other chloroplast regions that could separate the taxa within each cluster.

The locus $\operatorname{clpP}(30204)$ was tested on the basis that it was substantially polymorphic and has proved useful to discriminate among species in Ponderosae [12]; our assay showed that it correctly grouped $64 \%$ of the specimens identified as var. oaxacana from the rest of the analyzed taxa and was present in over $70 \%$ of the trees sampled from Oaxaca (Sierra del Sur, SMO). This represents an important achievement of the assay, since identification based on apophysis length and cone size provides variable results. Moreover, this variety grows in intermixed populations with var. pseudostrobus in southern Mexico and with var. apulcensis in Veracruz [3], allowing potential gene flow to occur among the taxa, further evidenced by the presence of this haplotype in var. pseudostrobus individuals from Puebla and Veracruz. Single-locus barcodes have revealed variable levels of success from $26 \%$ to $31 \%$ in Inga and Araucaria that increased to $32 \%$ and $69 \%$ when two or three loci were used [41] and up to seven loci have been used to discriminate up to 60\% of Picea species [48]. Interestingly, the $\operatorname{clp} P(30204)-2$ allele was detected sparingly in var. apulcensis only in one specimen from Veracruz and was never found in individuals of this taxon from Chiapas. The reasons for this are not clear; however, they may be related to limited sampling [49].

Here, we were unable to identify markers that could differentiate var. coatepecensis from the other taxa. Because P. pseudostrobus is very polymorphic, to date, the acceptance of var. coatepecensis is subject to controversy. In the 1940s, taxonomists recognized this variety following Martínez' [9] classification of the Pseudostrobus group; later, Stead [2] grouped this variety into subsp. apulcensis, based on needle anatomy and micromorphological characteristics. Since then, the recognition of the variety has remained discretional and specimens from regions in Veracruz, where this taxon is found, have not been included in more recent phylogenetic analyses, or are considered synonyms of var. pseudostrobus $[7,11,20]$. Our results are suggestive of the latter; yet, it is possible that var. coatepecensis consists of a 
particular ecotype with limited distribution and of recent diversification, so the discrimination from the other members of the complex may require the use of faster evolving loci, or exhibit subtler changes than those selected for this study (such as changes in single nucleotides).

Although establishing taxonomic limits and relationships within the Pseudostrobus complex is beyond the scope of this work, in the attempt to identify loci that associate with particular taxa for barcoding purposes, we provide further evidence of the usefulness of these less explored chloroplast regions to analyze relationships at lower taxonomic level in Pinus $[12,44,47,50,51]$. They also reflected the difficulties faced when attempting to assign a single locus for the discrimination of taxa, due to extensive sharing of alleles. Notwithstanding, our results show emerging patterns that are worthy of further consideration. The mapping of the different Pseudostrobus varieties showed a geographical effect on the prevalence of the different haplotypes (Figures 1 and 4). Over 85\% of the var. pseudostrobus from Michoacán and Jalisco and most of the Trans-Mexican Volcanic Belt (TMVB) identified morphologically corresponded closely to the type specimens and shared the predominant haplotype $\mathrm{A}$ and, in a few cases, rare alleles that gave rise to unique haplotypes $(\mathrm{E}, \mathrm{F}$ and G). However, as the TMVB spreads east and comes together with the Sierra Madre Oriental (SMO) in Puebla and Veracruz, the observed haplotype frequencies changed and there was a notorious increase in haplotypes B and C, that reached nearly $50 \%$. This is suggestive of increased gene flow among taxa in these transitional zones where different populations converge.

A similar geographical effect was also seen for var. apulcensis, where half of the specimens from eastern Hidalgo, near Apulco, where the type specimen was collected, shared haplotype $\mathrm{C}$ and appeared to be more closely related to P. montezumae, whereas the other half showed a unique haplotype J. In contrast, in the Sierra Madre del Sur, in Chiapas, the A haplotype predominated, whereas those from northern Veracruz were conformed mostly by the D haplotype, although various other less-represented variants were also present. This is consistent with other reports analyzing morphological traits [3] and could provide further explanation for the lack of resolution observed in most molecular phylogenetic analyses including these taxa [11,20]. This discontinuous pattern may indicate different geographic lineages for the varieties, with greater introgression or hybridization between P. pseudostrobus and P. montezumae occurring in the TMVB [7] and possibly var. estevezii from the northern range of the SMO, which was not included in this study.

The real-time PCR-HRM approach presented here also provided a means to identify different or rare alleles in wild-growing Pseudostrobus populations. The technique was sensitive enough to allow us to perform the discrimination of amplicons based on changes in a

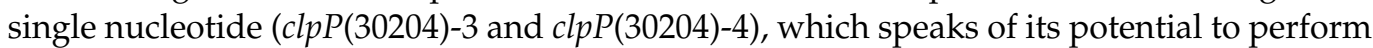
accurate large-scale screenings. These results are particularly important for low-budget labs without sequencing capacity, because PCR-HRM substantially reduces costs. Real-time PCR equipment with adequate sensitivity is becoming standard in many laboratories with molecular biology capabilities; furthermore, there is an increase in the number of companies that develop and supply reagents, so costs have lowered in consequence. The main caveat is the cost of specialized software for the HRM analysis, although freeware developed by universities or as part of R-based resources can circumvent this limitation if needed. Thus, the identification of informative markers for a non-model tree species remains the most relevant hurdle that can limit implementation and represents the most expensive phase during the establishment of a reproducible protocol. An important accolade to reduce costs and make the overall analysis more efficient would include the development of a multiplex assay.

\section{Conclusions}

Here, we describe the application of an HRM curve analysis for the inter- and intraspecific discrimination of individuals from wild populations of P. pseudostrobus and P. montezumae, using chloroplast SSP markers. Although none of the tested markers was able 
to produce clusters exclusive to a single variety, performing sequential real-time PCRs with a second marker usually allowed us to perform the discrimination of most of the taxa. The marker $c p D N A 10$ allowed us to conduct a relatively straightforward discrimination of two groups, P. pseudostrobus var. pseudostrobus/var. oaxacana and P. pseudostrobus var. apulcesis/P. montezumae. Afterward, the analysis with $\operatorname{clpP}(30204)$ permit us to perform the separation of $64 \%$ of the individuals identified as var. oaxacana. Discerning between P. pseudostrobus var. apulcensis and P. montezumae was successful in $83 \%$ of the cases. However, these markers did not discriminate between var. pseudostrobus/var. oaxacana from var. coatepecensis, reflecting the existing challenge encompassed in identifying phylogenetically informative molecular markers to establish taxonomic limits within the Pseudostrobus complex and other closely related species. However, the geographical effect on the distribution of eleven haplotypes, evidenced by this study, may support further research into the biogeography of the group. Even with its limitations, HRM shows great potential as a useful, fast and economical molecular tool for high-throughput intraspecific, as well as allelic, discrimination of wild populations of Pinus species.

Supplementary Materials: The following supporting information can be downloaded at: https:// www.mdpi.com/article/10.3390/f13020200/s1, Table S1: Location of collected specimens of different Pseudostrobus varieties and grouping according to haplotype as obtained by HRM analysis.

Author Contributions: Study conception and design, F.G.-C. and L.E.G.-V.; material preparation, J.V.-H. and R.R.-S.; experiments, L.E.G.-V., J.P.-G. and F.G.-C.; data analysis, L.E.G.-V., F.G.-C. and M.Á.V.-R.; writing—original draft preparation, F.G.-C. and L.E.G.-V.; writing—review and editing, J.V.-H. and M.Á.V.-R.; project administration and funding acquisition, J.V.-H. All authors commented on previous versions of the manuscript. All authors have read and agreed to the published version of the manuscript.

Funding: Fondo Sectorial para la Investigación, el Desarrollo y la Innovación Tecnológica Forestal, CONAFOR-CONACYT, Project CONAFOR-2016-4-277784 “Establecimiento de huertos semilleros asexuales regionales y ensayos de progenie de Pinus pseudostrobus para la evaluación genética de los progenitores".

Institutional Review Board Statement: Not applicable.

Informed Consent Statement: Not applicable.

Data Availability Statement: File enclosing geographical location of collected Pinus pseudostrobus samples in México, as well as haplotype grouping obtained from HRM analysis, can be accessed at zenodo.org/record/5768618\#.Ye8KQ_7MKUI.

Acknowledgments: This work could not have been completed without the exemplary assistance and expertise in the collection of field material of Martin Gómez-Cárdenas (INIFAP) and Nahúm SánchezVargas (Universidad Michoacana de San Nicolás Hidalgo) in Michoacán and Jalisco, Adán HernándezHernández (INIFAP) in Oaxaca, Guillermo Rodriguez and Jesús Dorantes López (Universidad Veracruzana) in Veracruz, and from Javier López-Upton (Colegio de Posgraduados) in Puebla, Tlaxcala, Hidalgo and Mexico State.

Conflicts of Interest: The authors declare no conflict of interest.

\section{References}

1. Farjon, A.; Styles, B.T. Flora Neotropica. Pinus (Pinaceae); New York Botanical Garden: New York, NY, USA, 1997.

2. Stead, J.W. A study of variation and taxonomy of the Pinus pseudostrobus complex. Commonw. For. Rev. 1983, 32, 101-112.

3. Stead, J.W.; Styles, B.T. Studies of Central American Pines: A revision of the 'pseudostrobus' Group (Pinaceae). Bot. J. Linn. Soc. 1984, 89, 249-275. [CrossRef]

4. Viveros-Viveros, H.; Sáenz-Romero, C.; López-Upton, J.; Vargas-Hernández, J.J. Variación genética altitudinal en el crecimiento de plantas de Pinus pseudostrobus Lindl. en campo. Agrociencia 2005, 39, 575-587.

5. Viveros-Viveros, H.; Saenz-Romero, C.; Jesus Vargas-Hernandez, J.; Lopez-Upton, J. Variacion entre procedencias de Pinus pseudostrobus establecidas en dos sitios en Michoacan, Mexico. Rev. Fitotec. Mex. 2006, 29, 121-126.

6. Perry, J.P., Jr. The Pines of Mexico and Central America; Timber Press: Portland, OR, USA, 1991; p. 231. 
7. Delgado, P.; Salas-Lizana, R.; Vázquez-Lobo, A.; Wegier, A.; Anzidei, M.; Alvarez-Buylla, E.R.; Vendramin, G.G.; Piñero, D. Introgressive Hybridization in Pinus montezumae Lamb and Pinus pseudostrobus Lindl. (Pinaceae): Morphological and molecular (CpSSR) evidence. Int. J. Plant Sci. 2007, 168, 861-875. [CrossRef]

8. López-Reyes, A.; de la Rosa, J.P.; Ortiz, E.; Gernandt, D.S. Morphological, molecular, and ecological divergence in Pinus douglasiana and P. maximinoi. Syst. Bot. 2015, 40, 658-670. [CrossRef]

9. Mártínez, M. Los Pinos Mexicanos, 2nd ed.; Ediciones Botas: Distrito Federal, México, 1948; p. 361.

10. Perez de la Rosa, J.; Harris, S.A.; Farjon, A. Noncoding chloroplast DNA variation in Mexican Pines. Theor. Appl. Genet. 1995, 91, 1101-1106. [CrossRef]

11. Gernandt, D.S.; Hernández-León, S.; Salgado-Hernández, E.; Pérez de la Rosa, J.A. Phylogenetic relationships of Pinus Subsection Ponderosae inferred from rapidly evolving cpDNA regions. Syst. Bot. 2009, 34, 481-491. [CrossRef]

12. Wofford, A.M.; Finch, K.; Bigott, A.; Willyard, A. A set of plastid loci for use in multiplex fragment length genotyping for intraspecific variation in Pinus (Pinaceae). Appl. Plant Sci. 2014, 2, 140002. [CrossRef]

13. Wang, X.R.; Tsumura, Y.; Yoshimaru, H.; Nagasaka, K.; Szmidt, A.E. Phylogenetic Relationships of Eurasian Pines (Pinus, pinaceae) Based on chloroplast Rbcl, MatK, Rpl20-Rps18 spacer, and TrnV intron sequences. Am. J. Bot. 1999, 66, 12131-12140. [CrossRef]

14. Bilgen, B.B.; Kaya, N. Chloroplast DNA variation and pollen contamination in a Pinus brutia Ten. clonal seed orchard: Implication for progeny performance in plantations. Turk. J. Agric. For. 2014, 38, 540-549. [CrossRef]

15. Um, Y.; Park, W.-K.; Jo, N.-S.; Han, S.-H.; Lee, Y. Phylogenetic analysis of pines based on chloroplast TrnT-TrnL intergenic spacer DNA sequences. J. For. Environ. Sci. 2014, 30, 307-313. [CrossRef]

16. Powell, W.; Morgante, M.; McDevitt, R.; Vendramin, G.G.; Rafalski, J.A. Polymorphic simple sequence repeat regions in chloroplast genomes: Applications to the population genetics of Pines. Proc. Natl. Acad. Sci. USA 1995, 92, 7759-7763. [CrossRef] [PubMed]

17. Semerikov, V.L.; Semerikova, S.A.; Dymshakova, O.S.; Zatsepina, K.G.; Tarakanov, V.V.; Tikhonova, I.V.; Ekart, A.K.; Vidyakin, A.I.; Jamiyansuren, S.; Rogovtsev, R.V.; et al. Microsatellite loci polymorphism of chloroplast DNA of Scots Pine (Pinus sylvestris L.) in Asia and Eastern Europe. Russ. J. Genet. 2014, 50, 577-585. [CrossRef]

18. Xie, Q.; Liu, Z.H.; Li, Z.Q. Taxonomic Status of Pinus henryi Using Multiplexed microsatellite markers. Genet. Mol. Res. 2015, 14, 4549. [CrossRef] [PubMed]

19. Ni, Z.; Zhou, P.; Xu, M.; Xu, L.A. Development and characterization of chloroplast microsatellite markers for Pinus massoniana and their application in Pinus (Pinaceae) Species. J. Genet. 2018, 97, 53-59. [CrossRef]

20. Hernández-León, S.; Gernandt, D.S.; Pérez de la Rosa, J.A.; Jardón-Barbolla, L. Phylogenetic relationships and species delimitation in Pinus Section Trifoliae inferred from Plastid DNA. PLoS ONE 2013, 8, e70501. [CrossRef] [PubMed]

21. Reed, G.H.; Wittwer, C.T. Sensitivity and specificity of single-nucleotide polymorphism scanning by High-Resolution Melting Analysis. Clin. Chem. 2004, 50, 1748-1754. [CrossRef]

22. Wittwer, C.T. High-Resolution DNA Melting Analysis: Advancements and limitations. Hum. Mutat. 2009, 30, 857-859. [CrossRef]

23. Hewson, K.; Noormohammadi, A.H.; Devlin, J.M.; Mardani, K.; Ignjatovic, J. Rapid detection and non-subjective characterisation of infectious bronchitis virus isolates using High-Resolution Melt Curve Analysis and a mathematical model. Arch. Virol. 2009, 154, 649-660. [CrossRef]

24. Li, W.; Matsuoka, M.; Kai, M.; Thapa, P.; Khadge, S.; Hagge, D.A.; Brennan, P.J.; Vissa, V. Real-Time PCR and High-Resolution Melt Analysis for rapid detection of Mycobacterium leprae drug resistance mutations and strain types. J. Clin. Microbiol. 2012, 50, 742-753. [CrossRef] [PubMed]

25. Bosmali, I.; Ganopoulos, I.; Madesis, P.; Tsaftaris, A. Microsatellite and DNA-Barcode regions typing combined with High Resolution Melting (HRM) analysis for food forensic uses: A case study on lentils (Lens culinaris). Food Res. Int. 2012, 46, 141-147. [CrossRef]

26. Ganopoulos, I.; Argiriou, A.; Tsaftaris, A. Microsatellite High Resolution Melting (SSR-HRM) analysis for authenticity testing of protected designation of origin (PDO) Sweet Cherry products. Food Control 2011, 22, 532-541. [CrossRef]

27. Xanthopoulou, A.; Ganopoulos, I.; Koubouris, G.; Tsaftaris, A.; Sergendani, C.; Kalivas, A.; Madesis, P. Microsatellite HighResolution Melting (SSR-HRM) Analysis for genotyping and molecular characterization of an Olea europaea germplasm collection. Plant Genet. Resour. Charact. Util. 2014, 12, 273-277. [CrossRef]

28. Solano, J.; Anabalón, L.; Encina, F. Identification case of evidence in timber tracing of Pinus radiata, using High-Resolution Melting (HRM) Analysis. Forensic Sci. Int. Genet. 2016, 21, e6-e9. [CrossRef] [PubMed]

29. Smith, B.L.; Lu, C.P.; Alvarado Bremer, J.R. High-Resolution Melting Analysis (HRMA): A highly sensitive inexpensive genotyping alternative for population studies. Mol. Ecol. Resour. 2010, 10, 193-196. [CrossRef]

30. Granados-Cifuentes, C.; Rodriguez-Lanetty, M. The Use of High-Resolution Melting Analysis for genotyping Symbiodinium strains: A sensitive and fast approach. Mol. Ecol. Resour. 2011, 11, 394-399. [CrossRef]

31. Henri, H.; Mouton, L. High-Resolution Melting Technology: A new tool for studying the Wolbachia endosymbiont diversity in the field. Mol. Ecol. Resour. 2012, 12, 75-81. [CrossRef]

32. Dang, X.D.; Kelleher, C.T.; Howard-Williams, E.; Meade, C.V. Rapid identification of chloroplast haplotypes using High Resolution Melting Analysis. Mol. Ecol. Resour. 2012, 12, 894-908. [CrossRef]

33. Ganopoulos, I.; Aravanopoulos, F.; Madesis, P.; Pasentsis, K.; Bosmali, I.; Ouzounis, C.; Tsaftaris, A. Taxonomic identification of mediterranean pines and their hybrids based on the High Resolution Melting (HRM) and TrnL approaches: From cytoplasmic inheritance to timber tracing. PLoS ONE 2013, 8, e60945. [CrossRef] 
34. Galuszynski, N.C.; Potts, A.J. Application of High Resolution Melt Analysis (HRM) for screening haplotype variation in a non-model plant genus: Cyclopia (Honeybush). PeerJ 2020, 8, e9187. [CrossRef] [PubMed]

35. Doyle, J.; Doyle, J. A rapid isolation procedure for small amounts of leaf tissue. Phytochem. Bull. 1987, 19, 11-15.

36. Thompson, J.D.; Higgins, D.G.; Gibson, T.J. CLUSTAL W: Improving the sensitivity of progressive multiple sequence alignment through sequence weighting, position-specific gap penalties and weight matrix choice. Nucleic Acids Res. 1994, 22, 4673-4680. [CrossRef] [PubMed]

37. Provan, J.; Soranzo, N.; Wilson, N.J.; Goldstein, D.B.; Powell, W. A low mutation rate for chloroplast microsatellites. Genetics 1999, 153, 943-947. [CrossRef] [PubMed]

38. Gouy, M.; Guindon, S.; Gascuel, O. Sea View Version 4: A multiplatform graphical user interface for sequence alignment and phylogenetic tree building. Mol. Biol. Evol. 2010, 27, 221-224. [CrossRef]

39. Edgar, R.C. MUSCLE: Multiple Sequence Alignment with high accuracy and high throughput. Nucleic Acids Res. 2004, 32, 1792-1797. [CrossRef]

40. Aragón-Peralta, R.D.; Rodríguez-Ortiz, G.; Vargas-Hernández, J.J.; Enríquez-del Valle, J.R.; Hernández-Hernández, A.; CamposAngeles, G.V. Selección fenotípica y características reproductivas de Pinus pseudostrobus var. oaxacana (Mirov) S.G.Harrison. Rev. Mex. Cienc. For. 2020, 11, 118-140. [CrossRef]

41. Hollingsworth, P.M.; Forrest, L.L.; Spouge, J.L.; Hajibabaei, M.; Ratnasingham, S.; van der Bank, M.; Chase, M.W.; Cowan, R.S.; Erickson, D.L.; Fazekas, A.J.; et al. A DNA barcode for land plants. Proc. Natl. Acad. Sci. USA 2009, 106, 12794-12797. [CrossRef]

42. Dong, W.; Xu, C.; Li, C.; Sun, J.; Zuo, Y.; Shi, S.; Cheng, T.; Guo, J.; Zhou, S. Ycf1, the most promising plastid DNA barcode of land plants. Sci. Rep. 2015, 5, 8348. [CrossRef]

43. Willyard, A.; Cronn, R.; Liston, A. Reticulate evolution and incomplete lineage sorting among the Ponderosa Pines. Mol. Phylogenet. Evol. 2009, 52, 498-511. [CrossRef]

44. Vendramin, G.G.; Lelli, L.; Rossi, P.; Morgante, M. A set of primers for the amplification of 20 chloroplast microsatellites in Pinaceae. Mol. Ecol. 1996, 5, 595-598. [CrossRef] [PubMed]

45. Dong, W.; Liu, J.; Yu, J.; Wang, L.; Zhou, S. Highly variable chloroplast markers for evaluating plant phylogeny at low taxonomic levels and for DNA barcoding. PLoS ONE 2012, 7, e35071. [CrossRef] [PubMed]

46. Parks, M.; Cronn, R.; Liston, A. Increasing phylogenetic resolution at low taxonomic levels using massively parallel sequencing of chloroplast genomes. BMC Biol. 2009, 7, 84. [CrossRef] [PubMed]

47. Celiński, K.; Kijak, H.; Wojnicka-Półtorak, A.; Buczkowska-Chmielewska, K.; Sokołowska, J.; Chudzińska, E. Effectiveness of the DNA barcoding approach for closely related conifers discrimination: A case study of the Pinus mugo complex. C. R. Biol. 2017, 340, 339-348. [CrossRef] [PubMed]

48. Ran, J.H.; Wang, P.P.; Zhao, H.J.; Wang, X.Q. A Test of seven candidate barcode regions from the plastome in Picea (Pinaceae). J. Integr. Plant Biol. 2010, 52, 1109-1126. [CrossRef]

49. Ledig, F.T.; Hodgskiss, P.D.; Krutovskii, K.V.; Neale, D.B.; Eguiluz-Piedra, T. Relationships among the spruces (Picea, Pinaceae) of Southwestern North America. Syst. Bot. 2004, 29, 275-295. [CrossRef]

50. Asaf, S.; Khan, A.L.; Khan, M.A.; Shahzad, R.; Lubna; Kang, S.M.; Al-Harrasi, A.; Al-Rawahi, A.; Lee, I.J. Complete chloroplast genome sequence and comparative analysis of Loblolly Pine (Pinus taeda L.) with related species. PLoS ONE 2018, 13, e0192966. [CrossRef]

51. Asaf, S.; Waqas, M.; Khan, A.L.; Khan, M.A.; Kang, S.M.; Imran, Q.M.; Shahzad, R.; Bilal, S.; Yun, B.W.; Lee, I.J. The complete chloroplast genome of wild rice (Oryza minuta) and its comparison to related species. Front. Plant Sci. 2017, 8, 304. [CrossRef] 